\title{
Pengaruh Penambahan Senyawa Berbasis Kitin terhadap Pertumbuhan Cendawan Entomopatogen Beauveria bassiana
}

\author{
Faradiba Lazuardi Rohman, Triono Bagus Saputro, dan Yusmani Prayogo \\ Departemen Biologi, Fakultas Ilmu Alam, Institut Teknologi Sepuluh Nopember (ITS) \\ Balai Penelitian Tanaman Aneka Kacang dan Umbi (Balitkabi) \\ e-mail: trionobsaputro@bio.its.ac.id
}

\begin{abstract}
Abstrak-Cendawan entomopatogen termasuk salah satu patogen serangga yang cukup penting karena dapat menekan populasi hama di lapangan. Beauveria bassiana merupakan salah satu cendawan entomopatogen yang memiliki kelebihan dalam menginfeksi hampir seluruh ordo dan berbagai stadia serangga, sehingga cukup prospektif digunakan sebagai alternatif pengganti insektisida kimia. Variasi virulensi dapat dipengaruhi beberapa faktor, baik faktor dalam, yaitu asal isolat, maupun faktor luar seperti medium untuk perbanyakan jamur. Sehingga untuk meningkatkan virulensi cendawan dapat dilakukan dengan cara menumbuhkannya pada media yang banyak mengandung kitin dari serangga atau diinfeksikan ulang pada serangga inang. Tujuan dari penelitian ini untuk mempelajari pengaruh kitin terhadap pertumbuhan Beauveria bassiana. Metode yang digunakan dengan cara menambahkan kitin serangga (Tenebrio molitor), cangkang crustacea (Penaeus merguiensis), dan cangkang mollusca (Anadara inflata) pada media pertumbuhan cendawan. Berdasarkan hasil pengamatan, perlakuan yang paling baik ada pada $P$ 2.2 dengan menunjukkan pertumbuhan diameter koloni lebih cepat dibandingkan lainnya yaitu mencapai $5.5 \mathrm{~cm}$ dalam waktu 20 hari. Serta karakter koloninya adalah wholly yang mengindikasikan pertumbuhan miselium yang lebih cepat.
\end{abstract}

Kata Kunci-Beauveria bassiana, cendawan, entomopatogen, kitin, virulensi.

\section{PENDAHULUAN}

$\mathrm{P}$ ENINGKATAN prevalensi serangan hama serangga saat ini disebabkan oleh perubahan iklim. Pengendalian hama serangga saat ini masih mengandalkan penggunaan insektisida kimia, akan tetapi belum menunjukkan hasil positif. Alternatif pengendalian hama secara biologis menggunakan hasil metabolit sekunder suatu organisme tertentu. Pada jenis tanaman tertentu telah diketahui sebagai insektisida potensial karena mengandung senyawa aktif, seperti minyak esensial, saponin, tanin, alkaloid, fenol, flavonoid, alkana, dan terpenoid [1]. Selain itu juga dapat menggunakan cendawan entomopatogen [2]. Cendawan entomopatogen termasuk salah satu patogen serangga yang cukup penting karena dapat menekan populasi hama di lapangan. Beberapa jenis cendawan entomopatogen yang telah dimanfaatkan untuk mengendalikan hama tanaman perkebunan dan sayuran adalah Metarhizium anisopliae, Beauveria bassiana, Paecilomyces sp., Lecanicillium sp., dan Spicaria sp. Pemanfaatan cendawan entomopatogen untuk mengendalikan hama merupakan salah satu komponen Pengendalian Hama Terpadu (PHT) [3].
B. bassiana (Bals.) Vuil. merupakan entomopatogen kosmopolitan, tumbuh alami di tanah dan bersifat patogen pada spesies serangga tertentu dan beberapa isolat dari $B$. bassiana telah dikomersialkan [4]. B. bassiana memiliki koloni berwarna putih, hifa pendek, dan bentuk spora bulat [5]. Konidiofor memiliki bagian fertil yang bercabang dengan bentuk zig-zag dan di ujungnya terbentuk konidia yang mirip bola. Konidia memiliki dinding yang licin, diameter 2-3 $\mu \mathrm{m}$, dan bersifat hidrofob. Hifa hialin, berbentuk massa yang berwarna putih atau kuning pucat, namun kadang berwarna merah muda atau kemerahan [6]. B. bassiana merupakan spesies jamur yang sering digunakan untuk mengendalikan serangga. B. bassiana menghasilkan racun (toksin) yang dapat mengakibatkan paralisis secara agresif pada larva dan imago serangga [7]. Beberapa racun yang telah berhasil diisolasi dari B. bassiana antara lain Beauvericine, Beauverolide, Isorolide, dan zat warna serta asam oksalat [6].

B. bassiana merupakan spesies cendawan yang sering digunakan untuk mengendalikan serangga karena dapat menginfeksi hampir seluruh ordo dan berbagai stadia serangga, sehingga cukup prospektif digunakan sebagai alternatif pengganti insektisida kimia [8][9]. Beberapa keunggulan biopestisida dari cendawan $B$. bassiana sebagai agen hayati untuk pengendalian hama antara lain: (1) mudah diperbanyak atau dikembang biakan di media alami atau buatan, (2) tidak menyebabkan resistensi pada hama sasaran, (3) aman terhadap lingkungan, sumber air, maupun ternak, serta (4) kualitas produk yang dihasilkan semakin meningkat karena produk yang dihasilkan bebas residu [10].

Kelemahan biopestisida yang berasal dari B. bassiana adalah penurunan virulensi akibat produksi secara massal pada media alami. Variasi virulensi dapat dipengaruhi beberapa faktor, baik faktor dalam yaitu asal isolat, maupun faktor luar seperti media pertumbuhan [11]. Kondisi ini disebabkan cendawan entomopatogen bersifat parasit dengan cara menginfeksi serangga inang sebagai sumber makanan untuk perkembangbiakan cendawan. Kitin merupakan salah satu sumber karbon yang sangat diperlukan untuk perkecambahan konidia cendawan [12]. Pertumbuhan hifa dan sporulasi dipengaruhi oleh keberadaan nutrien pada medium. Karbon dan nitrogen yang bersumber dari komponen medium merupakan unsur penyusun karbohidrat, asam nukleat, protein dan lipid. Molekul-molekul kompleks tersebut merupakan makromolekul utama penyusun sel hifa dan konidia cendawan 
[13]. Isolat yang virulen cenderung memiliki viabilitas konidia yang tinggi.

Sehingga untuk meningkatkan virulensi cendawan dapat dilakukan dengan cara menumbuhkannya pada media yang banyak mengandung kitin dari serangga atau diinfeksikan ulang pada serangga inang. Oleh karena itu dalam penelitian ini digunakan penambahan kitin untuk meningkatkan virulensi cendawan dengan menggunakan beberapa variasi kitin yang diperoleh dari kitin serangga (Tenebrio molitor), cangkang crustace (Penaeus merguiensis), dan cangkang mollusca (Anadara inflata). Penelitian ini bertujuan untuk mempelajari pengaruh kitin terhadap pertumbuhan $B$. bassiana.

\section{METODOLOGI}

\section{A. Waktu dan Tempat}

Perlakuan dan pengamatan pertumbuhan cendawan $B$. bassiana dilaksanakan di Laboratorium Biosains dan Rekayasa Tumbuhan Departemen Biologi FIA Institut Teknologi Sepuluh Nopember Surabaya dan di Laboratorium Biopestisida Balai Penelitian Tanaman Aneka Kacang dan Umbi (BALITKABI). Perlakuan selama persiapan sampai pemanenan dimulai dari bulan Agustus 2016 sampai bulan Januari 2017.

\section{B. Alat dan Bahan}

Alat yang dibutuhkan dalam praktikum ini adalah, Autoclave, Laminair Air Flow (LAF), Hot Plate, Oven, Timbangan analitik, Mikroskop compound, Mortar \& pestel, Saringan bertingkat, Pinset, Pipet tetes, Pisau, Panci, Botol kaca $100 \mathrm{ml}$, Cawan petri diameter $9 \mathrm{~cm}$, Gelas ukur, Gelas beaker, Gelas pengaduk, Jarum ose, Penggaris, Sendok, Corong, Bunsen.

Bahan yang digunakan dalam penelitian ini antara lain adalah isolat cendawan entomopatogen $B$. bassiana, yang diperoleh dari koleksi Laboratorium Biopestisida BALITKABI. Kitin yang digunakan dalam penelitian ini berasal dari kitin serangga ( $T$. molitor), cangkang crustace ( $P$. merguiensis), dan cangkang mollusca (A. inflata). Bahan lainnya yang dibutuhkan adalah kentang, dextrose, agar-agar, akuades steril, alkohol, asam laktat, spirtus, tissue, kapas, kertas label, kertas re-use, cling-wrap dan korek api.

\section{Cara Kerja}

\section{1) Pemurnian Isolat B. bassiana}

Isolat $B$. bassiana diperoleh dari koleksi Laboratorium Biopestisida BALITKABI. Isolat dimurnikan pada media Potato Dextrose Agar dengan metode Agar Plate sebanyak 20 cawan petri. Kemudian isolat diinkubasi selama 21 hari dalam suhu ruang $\left(27^{\circ} \mathrm{C}\right)$.

2) Pembuatan tepung kitin

Kitin yang digunakan dalam penelitian ini berasal dari integumen serangga, cangkang crustacea, dan cangkang mollusca. Serangga yang digunakan adalah $T$. molitor. Cangkang crustacea yang digunakan adalah cangkang $P$. merguiensis. Cangkang mollusca yang digunakan adalah cangkang A. inflata. Masing-masing jenis sumber kitin tersebut dikeringkan dibawah sinar matahari selama 3 hari, kemudian dilanjutkan dengan pengovenan dalam suhu $65^{\circ} \mathrm{C}$ sampai kering. Selanjutnya ditumbuk hingga halus hingga menjadi tepung. Kemudian tepung disaring, ukuran lolos saringan $0,600 \mathrm{~mm}$ yang digunakan.

3) Persiapan media kitin

Masing- masing jenis kitin sebagai perlakuan ditambahkan kedalam media tumbuh Potato Dextrose Agar (PDA). Penambahan kitin berdasarkan konsentrasi $0,5 \%$ dan $1 \%$ dalam $200 \mathrm{ml}$ media PDA. Kemudian media disterilisasi dalam autoclave selama 30 menit pada suhu $121^{\circ} \mathrm{C}$. Perlakuan kontrol hanya menggunakan media PDA tanpa bahan kitin. Setelah disterilisasi media tumbuh dituangkan kedalam cawan petri berdiameter $9 \mathrm{~cm}$ masing-masing sebanyak $10 \mathrm{ml}$ dan ditambahkan $1 \mathrm{ml}$ asam laktat $0,5 \%$. Dibuat pengulangan sebanyak 3 kali.

4) Inokulasi cendawan B. bassiana pada media kitin

Isolat cendawan $B$. bassiana yang sudah dimurnikan dan ditumbuhkan pada media PDA. Pada umur 21 hari setelah inokulasi (HSI) koloni dilubangi dengan menggunakan tabung reaksi steril diameter $1 \mathrm{~cm}$. Kemudian dipindahkan dengan menggunakan jarum ose kedalam media pertumbuhan yang mengandung kitin sesuai jumlah perlakuan. Setelah itu diinkubasi dalam suhu ruangan $\left(27^{\circ} \mathrm{C}\right)$. Inkubasi dilakukan selama 20 hari, dan dilakukan pengukuran diameter koloni setiap 5 hari.

\section{5) Karakter Koloni Cendawan B.bassiana}

Pada umur 20 HSI, pertumbuhan koloni cendawan dikarakterisasi dengan membandingkan pola pertumbuhan koloni cendawan berdasarkan metode yang dikembangkan oleh Rayner dan Boddy (1988) meliputi bentuk atau pola koloni, warna koloni dan kecepatan pertumbuhan koloni.

\section{6) Rancangan Penelitian dan Analisis Data}

Penelitian ini menggunakan Rancangan Acak Lengkap Faktorial (RAL Faktorial), ulangan tiga kali. Dengan dua faktor berupa jenis dan konsentrasi kitin. Kitin yang digunakan ada tiga jenis dan konsentrasi yang digunakan ada dua yaitu $0,5 \%$ dan $1 \%$. Disusun sebagai berikut:

P $1.1=$ kontrol tanpa kitin

P $1.2=$ kontrol tanpa kitin

P $2.1=$ kitin T. molitor konsentrasi $0,5 \%$;

P $2.2=$ kitin T.molitor konsentrasi $1 \%$;

P $3.1=$ kitin $P$. merguiensis konsentrasi 0,5\%;

P $3.2=$ kitin $P$. merguiensis konsentrasi 1\%;

P $4.1=$ kitin A. inflata konsentrasi $0,5 \%$;

P $4.2=$ kitin A. inflata konsentrasi $1 \%$.

Data yang diperoleh dari hasil pengamatan akan dianalisis ANOVA menggunakan software MINITAB 16 untuk mengetahui pengaruh jenis dan konsentrasi kitin yang berbeda terhadap peningkatan pertumbuhan cendawan $B$. bassiana. Apabila didapatkan perbedaan yang nyata dilanjutkan uji Tukey pada taraf nyata $\alpha=5 \%$.

\section{HASIL DAN PEMBAHASAN}

\section{A. Hasil Laju Pertumbuhan Koloni B. bassiana}

Lebih lanjut perlakuan P 2.2 mempunyai pertumbuhan koloni lebih cepat dibandingkan dengan perlakuan yang lain. Diameter koloni telah mencapai $5,5 \mathrm{~cm}$ dalam waktu 20 hari. Sedangkan pertumbuhan B. bassiana pada perlakuan media tumbuh kitin yang lain hanya mencapai kisaran $3-5 \mathrm{~cm}$. 
Tabel 1.

Rata-rata diameter koloni B. bassiana pada media pertumbuhan kitin 20 hari setelah inokulasi (HSI)

\begin{tabular}{ccc}
\hline \hline & \multicolumn{2}{c}{ Rata-rata diameter koloni (cm) \pm hari } \\
Jenis Kitin (A) & 1 & 2 \\
\hline 1 & $4.2 \pm 0.6 \mathrm{c}$ & $4.2 \pm 0.6 \mathrm{c}$ \\
2 & $4.3 \pm 0.1 \mathrm{c}$ & $5.5 \pm 0.2 \mathrm{a}$ \\
3 & $3.4 \pm 0.2 \mathrm{~d}$ & $4.4 \pm 0.3 \mathrm{bc}$ \\
4 & $4.2 \pm 0.5 \mathrm{c}$ & $4.8 \pm 0.9 \mathrm{~b}$ \\
\hline \hline
\end{tabular}

Keterangan: Angka yang diikuti huruf yang sama pada kolom yang sama tidak berbeda nyata menurut uji Tukey pada taraf nyata $5 \%$.

Jenis kitin: (1) kontrol tanpa kitin Konsentrasi: (1) 0,5\%
(2) T. molitor
(3) P. merguiensis
(4) A. Inflata

Pertumbuhan koloni $B$. bassiana terendah ada pada perlakuan P 3.1 yang hanya mampu mencapai $3,4 \mathrm{~cm}$ diamater koloninya dalam waktu 20 hari.

Perbandingan diamater tertinggi dan terendah menunjukkan perbedaan yang signifikan, hasil pengamatan diameter koloni secara lebih lengkap dapat dilihat pada (Tabel 1). Pertumbuhan koloni B.bassiana dipengaruhi oleh substrat atau media yang mengandung komponen nutrisi untuk pertumbuhan cendawan. Jenis dan konsentrasi kitin yang ditambahkan didalam media pertumbuhan memberikan pengaruh terhadap laju pertumbuhan koloni $B$. bassiana.

Pertumbuhan hifa dan sporulasi dipengaruhi oleh keberadaan nutrien pada medium. Karbon dan nitrogen yang bersumber dari komponen medium merupakan unsur penyusun karbohidrat, asam nukleat, protein dan lipid. Molekul-molekul kompleks tersebut merupakan makromolekul utama penyusun sel hifa dan konidia cendawan [13]. Substrat kitin merupakan sumber karbon dan nitrogen yang mendukung pertumbuhan miselium dan pembentukan konidia cendawan [14]. Media tumbuh juga harus mengandung protein untuk pembentukan spora, hifa apikal dan organe [15]. Penelitian ini menggunakan media PDA yang ditambahkan tepung kitin dengan konsentrasi berbeda yaitu $0,5 \%$ dan $1 \%$. Media PDA diketahui terdapat $20 \mathrm{~g}$ dextrose sebagai sumber karbohidrat. Cendawan mampu merombak karbohidrat dan bahan-bahan organik lainnya dengan reaksi enzimatik sehingga lebih mudah untuk asimilasi [16]. Substrat kitin merupakan sumber karbon dan nitrogen yang mendukung pertumbuhan miselium dan pembentukan konidia cendawan [14]. Hal serupa juga dibuktikan dalam penelitian Wijaya (2012), penambahan kitin kolodial 5\% (b/v), 10\% (b/v), maupun 15\%(b/v) pada biakan Metarhizium majus UICC 295 mengindikasikan adanya perbedaan kecepatan pertumbuhan hifa [13].

\section{B. Karakter Koloni B. bassiana}

Pengamatan morfologi koloni dilakukan pada hari ke-20 masa inkubasi.

Pada penelitian ini 8 perlakuan yang diuji menunjukkan bahwa koloni B. bassiana memiliki empat karakter yaitu; (1) cottony (hifa agak panjang dan menyebar ke segala arah), (2) velvety (hifa pendek, lurus dan tebal), (3) wholly (hifa atau kelompok hifa agak panjang, menebal, berbentuk seperti wol), (4) zonate (garis atau segmen konsentris dengan tekstur yang berbeda (Tabel 2).
Tabel 2

Karakteristik tekstur dan warna koloni $B$. bassiana pada media pertumbuhan kitin

\begin{tabular}{|c|c|c|c|}
\hline Nama & Warna & Tekstur & Deskripsi \\
\hline P 2.2 & Putih & Wholly & $\begin{array}{lll}\text { Hifa atau } & \text { kelompok hifa agak } \\
\text { panjang, menebal, } & \text { berbentuk } \\
\text { seperti wol } & & \end{array}$ \\
\hline P 4.2 & Putih & Cottony & $\begin{array}{l}\text { Hifa agak panjang dan menyebar } \\
\text { ke segala arah }\end{array}$ \\
\hline P 3.2 & Putih & Zonate & $\begin{array}{l}\text { Garis atau segmen konsentris } \\
\text { dengan tekstur yang berbeda }\end{array}$ \\
\hline P 2.1 & Putih & Wholly & $\begin{array}{l}\text { Hifa atau kelompok hifa agak } \\
\text { panjang, menebal, berbentuk } \\
\text { seperti wol }\end{array}$ \\
\hline P 4.1 & Putih & Cottony & $\begin{array}{l}\text { Hifa agak panjang dan menyebar } \\
\text { ke segala arah }\end{array}$ \\
\hline P 1.2 & Putih & Velvety & Hifa pendek, lurus dan tebal \\
\hline P 1.1 & Putih & Velvety & Hifa pendek, lurus dan tebal \\
\hline P 3.1 & Putih & Zonate & $\begin{array}{l}\text { Garis atau segmen konsentris } \\
\text { dengan tekstur yang berbeda }\end{array}$ \\
\hline
\end{tabular}

Keterangan: P 1.1 dan P 1.2: kontrol tanpa kitin, P 2.1 dan P 2.2: kitin T.molitor $0,5 \%$ dan $1 \%$, P 3.1 dan P 3.2: kitin P. merguiensis $0,5 \%$ dan $1 \%, \mathrm{P}$ 4.1 dan P 4.2: kitin A. inflata $0,5 \%$ dan $1 \%$.

Dari 8 perlakuan yang mengindikasikan karakter koloni cottony ada dua yaitu P 4.1 dan P 4.2 (Gambar 1a). Perlakuan yang membentuk karakter velvety ada dua yaitu $\mathrm{P} 1.1$ dan $\mathrm{P}$ 1.2 (Gambar 1b). Karakter koloni wholly ada dua yaitu P 2.1 dan P 2.2 (Gambar 1c). sementara itu yang membentuk karakter koloni zonate ada dua yaitu P 3.1 dan P 3.2 (Gambar 1d).
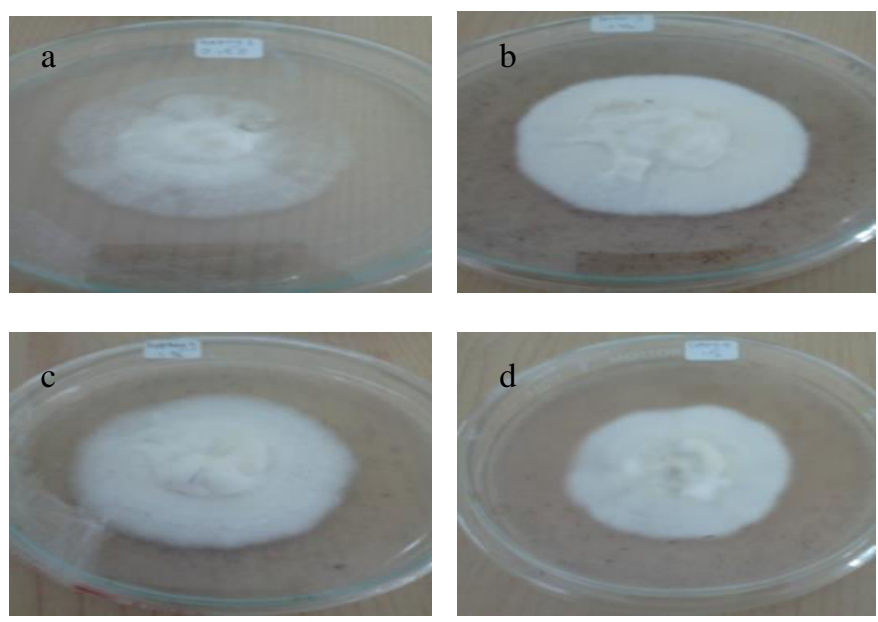

Gambar. 1. Karakter koloni B. bassiana yang berbentuk cottony (a), velvety (b), wholly (c), zonate.

Penambahan kitin pada konsentrasi yang berbeda tidak menyebabkan perubahan warna koloni cendawan B. bassiana. Warna koloni $B$. bassiana pada medium tumbuh yang mengandung kitin dari jenis kitin yang berbeda $T$. molitor, $P$. merguiensis, dan $A$. inflata adalah putih, namun dengan bertambahnya umur maka koloni berubah menjadi kuning pucat dan sedikit keruh. Menurut Rehner et al. (2011) cendawan $B$. bassiana yang virulen memiliki karakter koloni farinaceous dengan koloni berbentuk kapas dan bertepung, koloni berwarna putih kemudian berubah menjadi kuning pucat [16]. Sedangkan menurut Prayogo (2009) untuk memperoleh isolat cendawan Lecanicillium lecanii yang virulen harus menseleksi karakter koloni yang bersifat wholly dengan pertumbuhan miselium lebih cepat, miselium seperti 
berbulu, warna putih kapas, dan mampu memproduksi konidia dalam jumlah berlimpah. Pada perlakuan P 2.2 memiliki karakter koloni wholly dan merupakan koloni yang pertumbuhannya lebih cepat dibandingkan dengan perlakuan yang lain. Karakter koloni berhubungan dengan karakter fisiologi yang lain seperti virulensi, produksi konidia, dan periode waktu kecambah [17].

\section{KESIMPULAN}

Berdasarkan hasil pengamatan Beauveria bassiana yang ditumbuhkan pada media kitin yang berbeda dengan konsentrasi berbeda memberikan pengaruh. Laju pertumbuhan diameter koloni tertinggi ada pada (P 2.2) B. bassiana yang ditumbuhkan di media kitin T. molitor dengan konsentrasi $1 \%$, diameter mencapai $5,5 \mathrm{~cm}$ dalam waktu 20 hari masa inkubasi dan memiliki karakter koloni wholly. Sedangkan laju pertumbuhan terendah ada $(\mathrm{P} 3.1)$ pada B. bassiana yang ditumbuhkan di media kitin $P$. merguiensis dengan konsentrasi $0,5 \%$, diameter hanya mencapai $3,4 \mathrm{~cm}$ dalam waktu 20 hari dan memiliki karakter koloni zonate.

\section{DAFTAR PUSTAKA}

[1] K. I. Purwani, D.Ermavitalini, T. Nurhidayati, S. Nurhatika, and T. B. Saputro, "Exploration of Potential Plants as a Bio-Insecticide at ITS Surabaya Campus," KnE Life Sci, vol. 2, p. 662, 2015.

[2] S. Ondiaka, N. . Maniania, G. H. . Nyamasyo, and J. . Nderitu, "Virulence of The Entomopathogenic Fungi Beauveria bassiana and Metharizium anisopliae to Sweet Potato Weevil Cylas puncticollis and Effects on Fecundity and Egg Viability," Ann Appl Biol, vol. I-II, pp. 18-22, 2008.

[3] N. Jai, S. Rana, A. Kanojiya, and S.S Shandu, "Characterization of Beauveria bassiana Strains Based on Protease and Lipase Activity and Their Role In Patogenicity," J Basic Appl Mycol, vol. I-II, pp. 18-22, 2008.

[4] Y. Prayogo, W. Tengkano, and Marwoto, "Prospek Cendawan Entomopatogen Metarhizium anisopliae Untuk Mengendalikan Ulat Grayak Spodoptera litura Pada Kedelai," J. Litbang Pertan., vol. 24, no. $1,2005$.
[5] A. Nuraida and H. A, "Isolasi, Identifikasi dan Karakterisasi Jamur Entomopatogen Dari Rizosfir Pertanaman Kubis," J Hort, vol. 19, no. 4, pp. 419-432, 2009.

[6] P. . Purnama, S. . Nastiti, and J. Situmorang, "Uji Patogenitas Jamur Beauveria bassiana (Bals.) Terhadap Aphis craccivora Koch," BioSmart, vol. 5, no. 2, pp. 81-88, 2003.

[7] S. Mahr, "The Entomopathogen Beauveria bassiana, " University of Winconsin, Madison," Madison, 2016.

[8] N. N. Meyling and J. Eilenberg, "Ecology of The Entomopathogenic Fungi Beauveria bassiana and Metarhizium anisopliae in Temperate Agroecosystems: Potential for Conservation Biological Control," Biol. Control Elsevier, vol. 43, 2007.

[9] G. V. . Reddy, Z. Zhoo, and R. . Humber, “"Laboratory and Field Efficacy of Entomopathogenic Fungi for The Management of The Sweet Potato Weevil, Cylas formicarius (Coleoptera: Brentidae)," J Invertebr Pathol, vol. 122, pp. 10-15.

[10]R. Khosvari, J. . Sendi, A. Zibaee, and Shokrgozar, "Virulence of Four Beauveria bassiana (Bals.) (Asc: Hypocreales) Isolates on Rose Sawfly Arge Rosae Under Laboratory Condition," J. King Saud Univ. Sci, vol. 27 , no. 1 , pp. $42-53$.

[11]S. Herlinda, D. . Muhammad, P. Yulia, and Suwandi, "Kerapatan dan Viabilitas Spora Beauveria bassiana Akibat Subkultur dan Pengayaan Media, Serta Virulensinya Terhadap Larva Plutella xylostella (Linn.)," JHPT Trop., vol. 2, pp. 70-80.

[12] Y. Tanada and H.K. Kaya, Insect Pathology. New York: Academic Press, 1993.

[13]C. K. Wijaya, "Pengaruh Penambahan Kitin Kolodial 10\% Pasa Metarhizium majus UICC 295 Menginfeksi Larva Oryctes rhinoceros Linnaeu."

[14]C. Baretto, A. Staat, Schrank, and M. . Vainstein, "Distribution of Chitinases in The Entomopathogenic Metharizium anisopliae and Effect of N-acetylglucosamine in Protein Secretion," Curr. Microbiol., vol. 48, pp. 102-107.

[15]P. P. Taurisia, W. Meitini, Proborini, and I. Murhantoro, "The Effect of Media on The Growth and Biomass of Fungi Alternaria alternata (Fries) Keissler," J. Biol., vol. 19, no. 1, 2015.

[16]S. . Rehner, A. . Minnis, C. . Sung, J. . Luangsa-ard, L. Devotto, and R. . Humber, "Phylogeni adn Systematics of The Anamorphic Entomopathogenic Fungi Genus Beauveria," Mycologia, vol. 103, no. 5, pp. 1055-1073.

[17]Y. Prayogo, "Kajian Cendawan Entomopatogen Lecanicillium lecanii (Zimm.) (Viegas) Zare \& Gams Untuk Menekan Perkembangan Telur Hama Pengisap Polong Kedelai Riptortus linearis (F.) (Hemiptera: Alydidae)," Sekolah Pascasarjana Institut Pertanian Bogor. 